\title{
Antibody levels against hepatitis B vinus surface antigen among haemodialysis patients from two major Nephrology Units in Sri Lanka
}

\author{
WM Asmir ${ }^{1,3}$, S Mathu ${ }^{2}$, F Noordeen ${ }^{3}$
}

Introduction and Objectives: Haemodialysis patients are susceptible to hepatitis B virus (HBV) infection.Annual testing for antibody levels against HBV surface antigen (anti-HBs)in patients onhaemodialysis is recommended. If levels are less than $10 \mathrm{mIU} / \mathrm{mL}$, a booster vaccination is required. In the study sites, testing for anti-HBs levels is not done and thus the need for repeat vaccination cannot be identified. Our study aimed to quantify anti-HBs levels, identify factors associated with anti-HBs levels and test for HBsAg in those with anti-HBs $<10 \mathrm{mIU} / \mathrm{mL}$.

Methods: This study was done from November 2019 to April 2020 in 235 regular haemodialysis patients who had received three doses of hepatitis B vaccine in three different convenient schedules practiced by these Units in the last ten years (Table). Anti-HBs levels were quantified and analyzed with demographic factors such as age, gender, duration of chronic kidney disease, duration of dialysis, cycles of dialysis done per month, body mass index, serum creatinine and haemoglobin levels.

Results: Overall protection with anti-HBs $>10 \mathrm{mIU} / \mathrm{mL}$ was $69 \%$ with $80.4 \%$ for schedule C. Demographic factors did not show any association with anti-HBs levels apart from gender in schedule A where females had protection more than males. Among the 73patients with antiHBs levelof $<10 \mathrm{mIU} / \mathrm{mL}$, two were positive for HBsAg giving a prevalence of $2.7 \%$ for HBV infection among the vaccinated-unprotected haemodialysis patients.

Table: Anti-HBs levels in 235 haemodialysis patients attwomajornephrologyunits in Sri Lanka.

\begin{tabular}{|c|c|c|c|c|c|}
\hline \multirow{2}{*}{$\begin{array}{l}\text { HBV vaccination } \\
\text { schedules } \\
\text { practiced by the units }\end{array}$} & \multicolumn{3}{|c|}{ Anti-HBs levels (mIU/mL) } & \multirow[b]{2}{*}{$\begin{array}{c}\text { Overall } \\
\text { protection }\end{array}$} & \multirow[b]{2}{*}{ Total } \\
\hline & $\begin{array}{cl}<10 \\
\text { Not } & \text { protected }\end{array}$ & $\begin{array}{c}10-100 \\
\text { Protected }\end{array}$ & $\begin{array}{c}>100 \\
\text { Protected }\end{array}$ & & \\
\hline Schedule A (0, 1,2 months) & $49(33.1 \%)$ & $45(30.4 \%)$ & $54(36.5 \%)$ & 99 (66.9\%) & $148(100 \%)$ \\
\hline Schedule B (0, 1,3 months) & $13(41.9 \%)$ & $10(32.3 \%)$ & $8(25.8 \%)$ & 18 (58.1\%) & $31(100 \%)$ \\
\hline Schedule C ( $0,1,6$ months $)$ & $11(19.6 \%)$ & $13(23.2 \%)$ & $32(57.2 \%)$ & $45(80.4 \%)$ & $56(100 \%)$ \\
\hline & $73(31 \%)$ & $68(29 \%)$ & $94(40.0 \%)$ & $162(69 \%)$ & $235(100 \%)$ \\
\hline
\end{tabular}

Conclusions: Schedule C provided better protection compared to schedules A and B. A standard 4 dose schedule would achieve a better protection in these patients. Testing for postvaccination anti-HBs levels and monitoring the protection by annual testing must be done to maintain protection in haemodialysis patients according to the CDC recommendation.

Keywords: Anti-HBs levels, hepatitis B vaccine, HBsAg, haemodialysis patients, Sri Lanka

Funding: Medical Research Institute of Sri Lanka \& Sri Lanka College of Microbiologists.

\footnotetext{
${ }^{1}$ Postgraduate Institute of Medicine, University of Colombo, Sri Lanka

${ }^{2}$ National Institute for Nephrology, Dialysis and Transplantation, Colombo 10, Sri Lanka

${ }^{3}$ Department of Microbiology, Faculty of Medicine, University of Peradeniya, Sri Lanka
}

Address for correspondence: Dr. WM Asmir. Telephone: +94770812737 Email: wmasmir@gmail.com

(iD) https://orcid.org/0000-0002-5121-0900 